\title{
Gordy Slack, The Battle Over the Meaning of Everything: Evolution, Intelligent Design, and a School Board in Dover, PA
}

\author{
John Wiley \& Sons, 256 pp, \$24.95
}

\section{Andrea Barrett}

Published online: 20 November 2007

(C) Springer Science + Business Media, LLC 2007

In 1925, during the so-called 'monkey trial' in Dayton, Tennessee, Biblical creationists squared off against a high school teacher, John Scopes, who was charged with violating a state law that prohibited the teaching of evolution. Although the result was a public relations disaster, creationism has continued to gain strength, evolving new forms as it struggles to evade legal restrictions in the schools. The boundaries seem clear. In 1982, for instance, a federal court held in McLean v. Arkansas Board of Education that an Arkansas statute requiring 'balanced treatment'-balancing, that is, "creation science" and "evolution science"-was unconstitutional. In 1987, that ruling was strengthened (p. 105) when the Supreme Court overturned Louisiana's similar 'Creationism Act" in Edwards v. Aguillard, ruling that "creation science was a thinly veiled version of creationism, and that teaching it would promote a particular religious view, and hence violate the Establishment Clause of the First Amendment." (p. 105)

You might think it unlikely, then, that a school district would once more try to force the issue of teaching any form of creationism-yet that's exactly what happened in Dover, Pennsylvania in 2004. A board dominated by Christian fundamentalists passed an amendment to the science curriculum, stating: "Students will be made aware of gaps/problems in Darwin's theory and of other theories of evolution including, but not limited to, intelligent design." (p. 13)

"Intelligent design" (ID), the most recent version of antievolutionism, avoids mention of the Bible, but contends that life shows a specific type of "irreducible complexity" that cannot be produced by natural causes and must,

A. Barrett $(\bowtie)$

Williams College,

Williamstown, Massachusetts, USA

e-mail: abarrett@williams.edu therefore, have been caused by an "intelligent designer." The argument dates back at least as far as 1802, when William Paley published his Natural Theology. If we found a watch upon the ground, Paley argued, we would conclude from its intricate structure and function that it had been shaped for a purpose and must have had a maker. So, too, must we infer a Maker of such complex structures as the vertebrate eye. These days, ID proponents point to cellular or molecular structures like the bacterial flagellum and the blood-clotting cascade - without, however, describing how the design occurs. As an explanation, one leading theorist offers, "At some point, a supernatural designer must get into the picture." (p. 138; Slack quoting Behe)

In Dover, high school teachers and parents objected when the school board directed that copies of an ID-based textbook were to be placed in classrooms as a "curricular supplement," (p. 12) and that biology teachers must, before they taught anything about evolution, read to their students a prepared statement that included the following lines:

“Because Darwin's Theory is a theory, it continues to be tested as new evidence is discovered. The Theory is not a fact. Gaps in the Theory exist for which there is no evidence. A theory is defined as a well-tested explanation that unifies a broad range of observations. Intelligent Design is an explanation of the origin of life that differs from Darwin's view. The reference book, Of Pandas and People, is available for students who might be interested in gaining an understanding of what Intelligent Design actually involves.” (p. 15)

Sometimes in language almost identical to that of the 19th century and sometimes dressed in new ID clothes, all the old arguments against evolution were repeated as Kitzmiller et al. v. Dover Area School District et al. came to trial in September, 2005. In The Battle Over the Meaning 
of Everything, Gordy Slack, a science writer specializing in evolutionary biology and the intersection of science and religion, usefully delves into this territory.

Slack, originally assigned to cover the trial by the online magazine Salon.com, had an unusual personal stake in the argument. "I was an editor at a natural history magazine," he writes, "and the theme of my work was evolutionary biology....my dad [was] a Princeton-trained experimental psychologist who, to my dismay, had recently turned superChristian anti-evolution neo-creationist proponent of ID." (p. vii).

In the prologue, Slack promises that he will not only present to us the trial, the players, the essential arguments, and sufficient background to understand it all, but will explore the intense and loving relationship of a father and son who disagree passionately about philosophical and spiritual issues. As he summarizes his father's path from graduate student to burned-out ex-disciple of Timothy Leary, he notes, intriguingly, that:

that whole LSD scene engendered some habits that weren't conducive to career advancement. Two failed marriages, three university positions and a move to Australia later, Dad hit what in twelve-step jargon is known as 'the bottom.'...And so it was that in 1980 my Ivy League liberal intellectual dad became not only a tongues-speaking, born-again Christian but also a neo-creationist. (p. 20).

I was reminded here of Edmund Gosse's wonderful memoir, Father and Son (published in 1907), in which a doubting son, a writer interested in science and religion, examines his relationship with his devout father (the wellknown naturalist Philip Gosse, who was passionately opposed to evolution). However, although Slack promises to examine a similarly profound tension in his own family, in fact he mentions his father, after his opening gestures, only briefly.

I harp on that dropped thread, the chief defect in an otherwise lively and intelligent report about a crucial event in the culture wars, because Slack is otherwise so good at presenting the story's personal and political elements. His title is not merely hyperbolic, and his willingness to address the trial in terms of dueling world views lends his work urgency and focus. "Whatever happens at this trial," Slack writes,

"this argument will go on for a long time to come. Its roots reach not only into the American evangelical movement, but also down into the foundations of Western culture and philosophy. Is the world driven purely by matter and the laws of nature, or are those things mere embodiments of another, immaterial, intelligent aspect of the universe?" (p. 125)
Old questions, debated even before the 1859 publication of Darwin's On the Origin of Species. What Scots geologist Hugh Miller worried about in 1849, in The Footprints of the Creator, or, The Asterolepis of Stromness (a book so popular that it was reprinted numerous times through the end of the 19th century and into the 20th), still worries believers now. Miller wrote that, while the 'development hypothesis' might indeed be invoked to answer some of these questions, the results would be disastrous to our understanding of human nature:

"If, during a period so vast as to be scarce expressible by figures, the creatures now human have been rising, by almost infinitesimals, from compound microscopic cells - minute vital globules within globules, begot by electricity on dead gelatinous matter-until they have at length become the men and women whom we see around us, we must hold either the monstrous belief, that all the vitalities, whether those of monads or of mites, of fishes or of reptiles, of birds or of beasts, are individually and inherently immortal and undying, or that human souls are not so."

Fear of the consequences of that 'monstrous belief' still underlies anti-evolutionism. What went on in Dover was not so much an argument about competing scientific theories as about what science is, about how territory gets divvied up between religion and science, and about who gets to define those boundaries. There is more- or lessinvolved here, though, than a high-minded discussion of ideas. Summarizing the opening presentation of the plaintiffs' lead counsel, Slack explains that the case has:

...two strangely disproportionate prongs. One will address the immense questions underlying the crisis in Dover, in this case, and across our nation: What is science? What is religion? What is scientific truth? What is a theory? Where are we from? Is there a continuous chain of life linking us to ancient microbial ancestors? Can science say anything about the existence of God? The other prong of the plaintiffs' arguments deals with the smaller but legally crucial questions: Are the Dover school board members lying when they deny having talked about creationism at their meetings? Did they want to get religion back into their school, or were they promoting ID merely as an alternative scientific theory? (p. 28)

And indeed the trial's outcome will turn, as in any good story, on deceit and self-deceit, including a school board member's petty lies and the smooth maneuvers of the think-tank's lawyers; on our irresistible desire for selfaggrandizement; and on the large social consequences of small individual failures. (Several school board members, worn down by the fundamentalist faction, resigned in 
protest after a resolution was adopted. The dominant faction promptly filled their seats with "four superChristians whose primary qualifications were their clear support of the board's intelligent design policy.") (p. 14)

As Slack brings us through the trial, he alternates deft summaries of the expert witnesses' testimony with introductions to the major players and institutions on either side. Among those sketched are Phillip Johnson, one of the founders of ID: "urbane, articulate, and smart as a whip; not at all what I had expected to find in the guy who had resurrected creationism from the dung heap of some of America's really bad twentieth-century ideas" (p. viii); Michael Behe, who coined the term "irreducible complexity" (p. 128) and first presented the example of the bacterial flagellum (p. 131); and, on the opposing side, philosophers Robert Pennock (p. 70) and Barbara Forrest (p. 78), and evolutionary biologist and textbook author Kenneth Miller (p. 30). Swiftly and clearly, Slack also describes the evolution of both the Seattle-based Discovery Institute's Center for Science and Culture (the intellectual home of ID) (p. 75), and the National Center for Science Education, a nonprofit organization dedicated to defending the teaching of evolution in the public schools (44).

Media coverage of this trial was extensive, producing such excellent articles as H. Allen Orr's New Yorker piece, "Devolution: Why Intelligent Design Isn't" (May 30, 2005) and Jerry Coyne's review in The New Republic, "The Faith That Dare Not Speak Its Name: The Case Against Intelligent Design" (August 22 and 29, 2005). Both cover certain areas more thoroughly than Slack's book, which does not pretend to be definitive. It also lacks even the modest scholarly gestures of an index or a bibliography, which can make it hard to cross-check certain strands.

What it does do, however, is introduce the debate in such an approachable, conversational fashion that even the reader with no background in the area will be drawn into the drama. Slack has a good reporter's instinct for the telling detail and the vivid image, and he is able to synthesize and bring fresh perspective to a great deal of material, opening up the field for the less experienced reader. I would not have found the Orr and Coyne articles without The Battle Over the Meaning of Everything, which also drove me to read Behe's disturbingly popular Darwin's Black Box: The Biochemical Challenge to Evolution and see for myself how it might sway a person who knows little biology. Slack's book led me to Richard Dawkins' The Blind Watchmaker, to the excellent collection edited by Andrew Petto and Laurie Godfrey, Scientists Confront Intelligent Design and Creationism, and to Ronald Numbers' monumental and fascinating history, The Creationists. Through it, I also found the useful NCSE website http:// www.ncseweb.org), which offers bibliographies, history, and teaching materials.

This book made me curious; it made me want to dig more deeply. That is a wonderful quality, and in the end that is what I admired about it the most.

Andrea Barrett is the author of eight works of fiction, most recently Servants of the Map and The Air We Breathe (published in October). Among her characters are both actual and invented scientists wrestling with the ideas of evolution. 